\title{
ALTERNATIVE REAL VALUE HYBRID MODEL FOR THE VALUATION OF REVERSIONARY LEASEHOLD INVESTMENT PROPERTIES
}

\author{
Joseph Obaje Ataguba \\ Department of Estate Management and Valuation \\ The Federal Polytechnic Idah, Kogi State, Nigeria \\ josephtgb81@gmail.com
}

\begin{abstract}
This study is a design of an alternative real value hybrid model for the valuation of reversionary leasehold investment properties characterized by divergence in the revision period of sub-rent and head rent respectively. The development of this model commenced with a synthesis of inputs for the modified rational- and real value hybrid models, and the derivation of an equivalent cash flow multiplier for terminal investments. With exception of the generic real value model, term incomes across all other contemporary models including the alternative real value hybrid model were discounted using the equated yield. The discounted reversionary cash flows in the valuation template associated with the alternative real value hybrid model appears identical to that in the generic real value model, while exhibiting itself as a surrogate reversionary income multiplier for the modified rational, and the real value/short-cut DCF models respectively. The alternative real value hybrid model was validated as capable of producing valuations that are identical to those churned out from all the existing contemporary models for the valuation of this category of reversionary leasehold investment property. The study is a novel attempt towards redesigning the modified rational model of leasehold investment property valuation and according it a real value perspective.
\end{abstract}

Key words: alternative real value hybrid model, explicit DCF valuation, property investment valuation, contemporary models, reversionary leaseholds.

JEL Classification: $D 46, R 30$.

Citation: Ataguba, J. O. (2020). Alternative real value hybrid model for the valuation of reversionary leasehold investment properties. Real Estate Management and Valuation, 28(4), 63-80.

DOI: https://doi.org/10.1515/remav-2020-0032

\section{Introduction}

Property investment valuation is predicated on the discounting of streams of cash flows from landed property. The mathematical foundation for this exercise is anchored on compound interest model deployed over the years to solve parameters like the future value of a lump sum, compound interest earned, compound interest rate, and the time horizon of an investment. Specifically, property investment valuation deals with the calculation of the present value of annuity comprising that received (passing rent) and that expected (market rent) as at the date of valuation. Given the interaction among the variables that make up the model of property investment value, a crucial task is to understand the synergies among these models and their input variables and possibly explore avenues for the development of alternative models.

A common activity among scholars in the field of property investment valuation over the years has revolved around reflecting upon: the logic and rationale of existing models; the relationships among existing models with recourse to their input parameters; evolving new or alternative models by unmasking the input parameters of existing models; and evolving new or alternative models through 
a synthesis of two or more distinct models and formulas designed to confront a valuation problem from the same perspective.

Leasehold is a limited duration interest in property created by a contract conferring rights of possession and use on a benefitting party in exchange for the payment of rent to be enjoyed by the party granting such usufruct rights (Elias, 1971; Smith, 2007). Leasehold is seen as an investment with a limited duration (Fraser, 1993; Sayce, et al., 2006; Baum, et al., 2011), implying that the capital and rental values of the interest vanishes when the tenure expires. With respect to contemporary leasehold valuations, the real value/equated yield hybrid model (Crosby, 1983, 1984) herein referred to as the real value hybrid model (Crosby, 1986c) contains inputs that are surrogates of related inputs in the modified rational model developed by Baum and Shi Ming, (1985b). In other words, there is a possibility that the current equation and template for the modified rational model of leasehold valuation could be redesigned to use the same inputs as the real value hybrid model, and replace the 3-in-1 composite Years Purchase [YP] formula with a surrogate function which incorporates the deferment of the reversionary capital value using the present value [PV] of 11 in the period to the next rent review at the inflation risk free yield.

Although it is arguable to say that the contemporary value models were not designed to compete for supremacy but to avail valuers with an array of alternative valuation models for use in practice (Crosby, 1996; Crosby, et al., 1997), the research question put forward is: In what other form can the modified rational model be redesigned to mimic and use the same inputs as the real value hybrid model for the purpose of valuing reversionary leaseholds characterized by simultaneous revision of sub-rent and head rent but at different review periods? Specific objectives put forward to answer this research question include: a synthesis of model parameters for the modified rational model and the real value hybrid models of reversionary leasehold valuations; deriving a surrogate for reversionary income multiplier deferred for the period to the next rent review; redesigning an alternative real value hybrid model using the surrogate for reversionary income multiplier and the deferment factor; conducting a hypothetical valuation of reversionary leasehold investment property using the alternative real value hybrid model; and validating the alternative real value hybrid model using the four existing contemporary value models for leasehold interest.

While acknowledging, from the seminal works of Brown and Matysiak (2000) and Crosby and Henneberry (2010), that the comparative method of valuation remains fundamental to the derivation of capitalization rates and the valuation of property interests, this study is limited exclusively to the case of using discounted leasehold annuities as surrogates of market value especially in inefficient markets characterized by non-uniform growth rates in sub-rent and head-rents respectively. It is expected that a synthesis of the modified rational model developed by Baum and Shi Ming (1985b) with the analytical surrogates of inputs in the existing real value hybrid model by (Crosby, 1983, 1984) would accord "real value" dimension to the modified rational model and evolve into an alternative real value hybrid model for the valuation of reversionary leaseholds.

\section{Literature review and analytical framework}

\subsection{Antecedents of the contemporary value models for leaseholds}

The evolution and use of the contemporary models of property investment valuation were predicated on the logic of discounting growth-bound cash flows using the appropriate growth explicit yields, contrary to the erroneous notion that the cash flows remain static throughout the unexpired term (Ajayi, 1998; Brown \& Matysiak, 2000; Baum \& Crosby, 2007). The reverse yield gap being a phenomenon where bond yields became higher than initial yields of property (Baum \& Crosby, 2007), constituted one of the drivers behind the evolution of the contemporary models for the valuation of freehold and leasehold interests. Coinciding with reverse yield gap phenomenon was the sustained criticism against the use of dual rate Years Purchase (YP) to value leasehold incomes (Colam, 1984; Baum \& Shi Ming, 1985a; Baum \& Butler, 1986; Baum \& Crosby, 2007; Baum et al., 2011). Even where the use of single rate YP was suggested (Colam, 1984), critics still argued that the conventional techniques for the valuation of leasehold interests should be discarded in favour of growth explicit DCF valuation techniques (Baum \& Crosby, 2007). Most importantly, antecedents of contemporary models of leasehold investment property valuation can be traced to the flaws surrounding subjective adjustment of term and reversionary yields in the conventional single- and dual rate models (Baum \& Shi Ming, 1985b; Baum \& Crosby, 2007). 


\subsection{The variants of reversionary leasehold investment properties}

The three types of reversionary leaseholds that impact upon the structure of equations (models) used to determine their market capital values include: reversionary leaseholds where rent paid is fixed, reversionary leaseholds characterized by a growth-bound market head rent, and reversionary leaseholds where rent paid and rent received are subject to different revision periods and grow throughout the term of the sub-lease.

The third category of reversionary leasehold, which is the focus of this study, is characterized by a divergence in the revision period of sub-rent and head rent, and culminates into a complex cash flow structure. As indicated in Figure 1, the review pattern for sub-rent on a $t_{0}(3)$ yearly basis is different from that of the head rent on a $t_{1}(5)$ yearly basis. This difference in the revision periods $\left(t_{0}\right.$ and $\left.t_{1}\right)$ for cash inflows and cash outflows further differentiates the implied growth rates of sub-rents from that of the head rent.

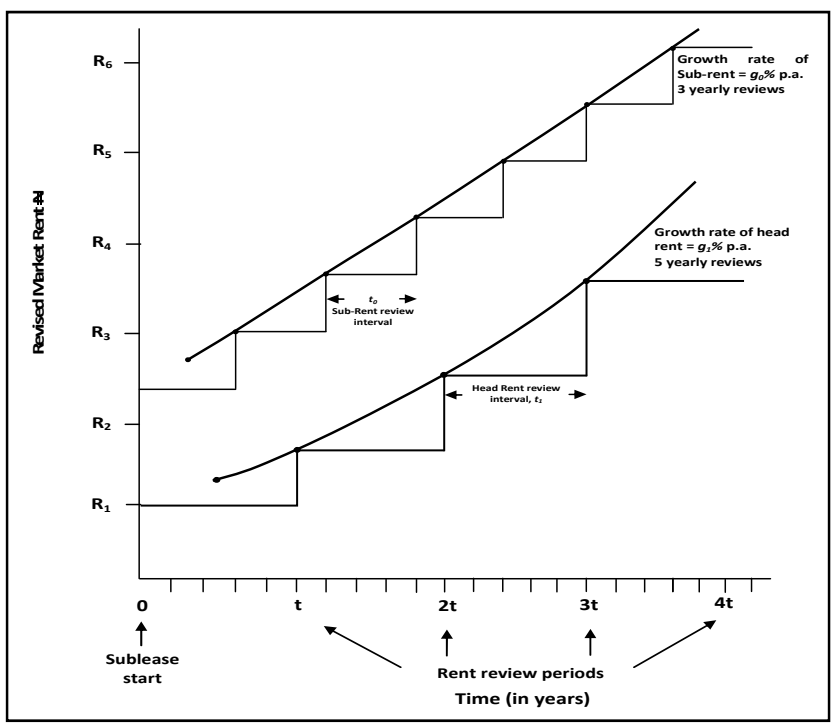

Fig. 1. Different revision periods for sub-rent and head rents. Source. Own study.

The complex cash flow structure in Figure 1 invalidates the continuous use of conventional techniques and favours the application of any variant of the contemporary valuation model. Recalling that the contemporary value models are not designed to compete for supremacy but to offer alternative toolkit for the valuer (Crosby, 1996; Crosby et al., 1997), there is a need to explore possibilities of evolving an alternative real value hybrid model for the market valuation of this third category of reversionary leasehold properties.

\subsection{Contemporary models for the valuation of reversionary leaseholds}

Property valuation scholars have debated on the distinction between market value (value-inexchange) and investment value (value-in-use) (Baum \& Crosby, 2007; Baum, et al., 2011; Olajide, et al., 2016). Baum, et al. (2011) argued that an asset that cannot be exchanged in the market for its monetary equivalent has no market value (value-in-exchange). However, it is apparent that an asset without value-in-use (investment value) would not be offered for exchange in the market. On the other hand, the term "market value" implies the existence of a probable purchaser of an interest (Baum, et al., 2011), whose purchase decision might be driven by a motive or collection of motives (utility). Hence, the empirical assertion that utility creates value (Harvey \& Jowsey, 2004). Underlying the investment method of valuation and its variants is the assumption that market value equals the sum of discounted annuities. Since this valuation method entails using comparable capitalization rates to discount property cash flows (Brown \& Matysiak, 2000; Baum, et al., 2011), it is obvious from the seminal works of Baum and Shi Ming (1985b); Crosby (1986b, 1986a); Sayce, et al. (2006); Baum and Crosby (2007); Jefferies (2016); and Sykes (1984) that the contemporary variants of this valuation method can be deployed to determine investment value (worth) and market value respectively. Notwithstanding, the leasehold investment valuation models presented in this article are predicated 
on the income approach which perceives the sum of discounted ordinary annuities as a surrogate of market value.

With respect to the contemporary models for the valuation of reversionary freeholds, the following symbols and their associated meanings have been maintained throughout this study:

$P V=$ Capital value of leasehold property

$r 0=$ Passing head rent

$R_{0}=$ Passing leasehold rent

$R_{1}=$ Leasehold market rent

$t_{0}=$ Review period of sub-rent

$g_{0}=$ Implied growth rate of sub-rent

$e=$ Leasehold equated yield

$n=$ Years to the next sub-rent review

$i_{0}=$ Inflation risk free yield of sub-rent

$k_{0}=$ All risks yield of leasehold income

$r_{1}=$ Market head rent

$t_{1}=$ Review period of market head rent

$g_{1}=$ Implied growth rate of head rent

$m=$ Years to the next head rent review

$i_{1}=$ Inflation risk free yield of head rent

$k_{1}=$ All risks yield of head rent

$N=$ Unexpired term of leasehold interest

In view of the symbols and their meanings above, the existing contemporary models for the valuation of ordinary annuities from leasehold investment properties are examined in the subsections below.

\subsubsection{The full DCF valuation technique}

The full discounted cash flow [DCF] technique for the valuation of leasehold investment properties entails the tabulation and valuation of rent received (cash inflow) and rent paid (cash outflow), the difference in which amounts to the capital value [Net Present Value] of the leasehold interest. For the rent received and rent paid, the tabulation involves about eight columns, comprising: the interval of cash flow, the rent projection factor using the compound interest formula at the implied rental growth rate, the projected rent, Years Purchase for the interval of cash flow and at the equated yield, Present Value of 1 at a cumulative period prior to that of the assessed cash flow tranche, discounted cash flows, and possibly, the present values of the cash flows. Valuers are not restricted in practice to adopt the full DCF technique for market valuations insofar as the application is informed by available market data (French, 2012). Nonetheless, there are some clients that may specifically request that their leasehold interests be valued using the DCF technique, especially when they desire to amass information regarding the implication of market growth expectations on the exit value.

The full DCF technique is not without challenge. An instance is the irreconcilable valuation in the last tranche of discounted cash inflow and/or cash outflow leading to an over valuation caused by the inability of the DCF technique to adjust rents across different review patterns (Baum \& Shi Ming, $1985 \mathrm{~b}$ ) and the inability of the technique to adapt itself to the valuation of cash flows where the period to the next rent reversion is not a multiple of the rent review period (Crosby, 1984; Isaac, 2002). In the event of this challenge, either equation 1 or 2 can be used to find the nominal cash flow which equates with the preceding cash flows on a rent review period/interval different from the preceding tranche:

$$
\begin{gathered}
R_{1}^{\prime}=R_{1} \times \frac{\text { Y.P. for } t_{0} \text { years@e }}{\text { Y.P. for } t_{0} \text { years@i } i} \times \frac{Y . P . \text { for } t_{1} \text { years@i } i}{\text { Y.P. for } t_{1} \text { years@e }} \\
R_{1}^{\prime}=R_{1} \times \frac{(1+e)^{t_{0}}-1}{(1+e)^{t_{0}}-(1+g)^{t_{0}}} \times \frac{(1+e)^{t_{1}}-(1+g)^{t_{1}}}{(1+e)^{t_{1}}-1}
\end{gathered}
$$

Where $R_{l}^{\prime}$ is the revised equivalent of the market rent in nominal terms, $R_{1}$ represents the market rent at the preceding review pattern, $t_{0}$ is the preceding rent review period, $t_{1}$ is the succeding rent review period, $e$ is the equated yield, $i$ is the inflation risk free yield, and $g$ is the implied rental growth rate.

\subsection{2 "Modified" Rational model for the valuation of leasehold investment properties}

McIntosh and Sykes (1983) and Sykes (1984) pioneered the development of a rational valuation model for leasehold investment properties. Sykes (1984) asserted that the term "rational" was used to name a valuation model that captures the behavior of property investment markets, values fixed term rents using nominal yield, and values growth induced rack rents using cap rates embedded with rent review period. Clarifying this term Baum and Crosby (2007) assert that "rational" valuation entails incorporating observable price changes in the inputs for the valuation of comparable assets. 
Baum and Shi Ming (1985a) later discovered that the originally developed Syke's rational model was fraught with incomplete model elements, resulting in the valuations churned out from the model failing to reconcile across the other contemporary value models, let alone the inability of the original model to treat gearing effects in the valuation of leasehold profit rents. In response, Baum and Shi Ming (1985b) re-engineered the original model and came up with the modified rational model. For the purpose of leasehold investment properties characterized by revisable cash inflows and cash outflows, the appropriate variant of the modified rational model for its valuation is stated as:

$$
P V=\left[\left(R_{0}\left(\frac{\left(1-(1+e)^{-n}\right)}{e}\right)\right)+\left(\frac{R_{1}}{k_{0}}\left(\frac{\left(1+g_{0}\right)^{n}}{(1+e)^{n}}-\frac{\left(1+g_{0}\right)^{N}}{(1+e)^{N}}\right)\right)\right]-\left[r_{0}\left(\frac{\left(1-(1+e)^{-m}\right)}{e}\right)+\left(\frac{r_{1}}{k_{1}}\left(\frac{\left(1+g_{1}\right)^{m}}{(1+e)^{m}}-\frac{\left(1+g_{1}\right)^{N}}{(1+e)^{N}}\right)\right)\right]
$$

Even after correcting the errors in Syke's original rational model, Baum and Shi Ming (1985b) still recommended the use of explicit DCF valuation techniques for leasehold valuation.

\subsubsection{Real value hybrid model for the valuation of leasehold investment properties}

The real value hybrid model for the valuation of leasehold investment properties is credited to the seminal works of Crosby (1983), Crosby (1984), Crosby (1986a), and Crosby (1986b). The development of this variant of the real value model can be traced to the preceding seminal works of Marshall (1976) and Wood (1986) tagged the "Equated yield-" and the "real value-" models respectively. Equation 4 is the "real value/equated yield hybrid model" herein referred to as the real value hybrid model for the valuation of leasehold investment properties with reversion of both rent received and rent paid.

$P V=\left[R_{0}\left(\frac{\left(1-(1+e)^{-n}\right)}{e}\right)+R_{1}\left(\frac{Y . P . t_{0} \text { years } @ e \times Y . P .(N-n) \text { years } @ i_{0}}{Y . P . t_{0} \text { years } @ i_{0} \times\left(1+i_{0}\right)^{n}}\right)\right]-\left[r_{0}\left(\frac{\left(1-(1+e)^{-m}\right)}{e}\right)+r_{1}\left(\frac{\left.Y . P . t_{1} \text { years@e } \times Y . P .(N-m) \text { years } @ i_{1}\right)}{Y . P . t_{1} \text { years } @ i_{1} \times\left(1+i_{1}\right)^{m}}\right)\right]$

Just as in equation 3 , the term rents received and paid in equation 4 are discounted using the equated yield. The only exception in equation 4 is that the revised rents received and paid are valued using a composite 3-in-1 Years' Purchase (YP) formula that incorporates the nominal- and real yields, standard rent review period, and the period to reversion of leasehold interest calculated as the difference between the entire term and the period to the next rent review.

\subsubsection{The generic real value model for the valuation of leasehold investment properties}

The Jefferies' generic real value model is a variant of the real value contemporary models of property investment valuation that arose from the seminal works of Rodney Lynn Jefferies: Jefferies (1997a), Jefferies (1997b), Jefferies (2009). In addition to the generic real value model, Jefferies (2010) developed the all risks real yield (ARRY) model to supersede the generic real value model that was originally developed in the late 1990s. According to Jefferies (2016), the ARRY model determines the capital value of interests in property by applying "real value" capitalization rates on the expected real term and reversionary cash flows unlike all previous real value models including the generic real value model that exhibit elements of nominal yield capitalization. A review of the ARRY model is outside the scope of this study since the author of the model reiterated that it is still a work in progress (Jefferies, 2018). Instead, this study examined the synergy of the alternative real value model with the generic real value model.

According to Jefferies (2009), the generic real value model for reversionary leaseholds is expressed as:

$$
C M V=\left\{C_{r}+V_{r}\left[\left(1+Y_{A}\right)^{-n}-\left(1+Y_{A}\right)^{-N}\right]\right\}-\left\{C_{p}+V_{p}\left[\left(1+Y_{A}^{\prime}\right)^{-m}-\left(1+Y_{A}^{\prime}\right)^{-N}\right]\right\}
$$

Where variables carrying the subscripts $r$ and $p$ relate to rent received and rent payable respectively. In consonance with the symbols for generic real value model, equation 5 can be transformed into equation 6 as:

$C M V=\left[\left(\frac{C_{0}}{R_{A}^{T}}\left(\frac{\left(1+Y_{A}\right)^{n}-1}{\left(1+Y_{A}\right)^{n}}\right)\right)+\left(\frac{C_{c}}{R_{A}^{F}}\left(\frac{1}{\left(1+Y_{A}\right)^{n}}-\frac{1}{\left(1+Y_{A}\right)^{N}}\right)\right)\right]-\left[\left(\frac{C_{0}^{\prime}}{R_{A}^{T^{\prime}}}\left(\frac{\left(1+Y_{A}^{\prime}\right)^{m}-1}{\left(1+Y_{A}^{\prime}\right)^{m}}\right)\right)+\left(\frac{C_{c}^{\prime}}{R_{A}^{F^{\prime}}}\left(\frac{1}{\left(1+Y_{A}^{\prime}\right)^{m}}-\frac{1}{\left(1+Y_{A}^{\prime}\right)^{N}}\right)\right)\right]$

At this juncture, there is a need to show the synergy between the semantics and symbolisms of the generic real value valuation model with those of the UK contemporary value valuation models where it exists: $C_{0}=R_{0}=$ Passing leasehold rent; $C_{c}=R_{1}=$ Leasehold market rent; $C_{0}^{\prime}=r_{0}=$ Passing head rent; 
$C_{c}^{\prime}=r_{1}=$ Market head rent; $T=n=$ Number of years to next upward review of rent; $F=t=$ Rent review period; $Y_{A}=i_{0}=$ Inflation risk free yield of cash inflow; $Y^{\prime}{ }_{A}=i_{1}=$ Inflation risk free yield of cash outflow; $R_{A}^{T}=$ All risks yield of term cash inflow; $R_{A}^{T^{\prime}}=$ All risks yield of term cash outflow; $R_{A}^{F}=$ $k_{0}=$ All risks yield of reversionary cash inflow; $R_{A}^{F^{\prime}}=k_{1}=$ All risks yield of reversionary cash outflow; $G_{0}=$ Nominal growth rate; $G_{r}=$ Real growth rate; $I_{e}=$ expected inflation rate; $Y_{0}=e=$ equated yield $=$ $\left(Y_{A}+I_{e}+G_{r}\right)$; Implied rental growth rate $=g=\left(I_{e}+G_{r}\right)$; and CMV = Current market value $=$ PV = Capital value of interest in property.

The analytical content and formulae for the calculation of $R_{A}^{T}, R_{A}^{T^{\prime}}, R_{A}^{F}$, and $R_{A}^{F^{\prime}}$ were adequately explained in Jefferies (1997a); Jefferies (2009); and Jefferies (2010). Therefore, the Jefferies' generic real value model for the valuation of reversionary leasehold can be expressed in a format that is consistent with the UK real value models except for the retention of new parameters comprising a distinct all risk yield for contract rent received $R_{A}^{T}$, and a distinct all risk real yield for head rent paid $R_{A}^{T^{\prime}}$ respectively:

$$
P V=\left[\left(\frac{R_{0}}{R_{A}^{T}}\left(\frac{\left(1+i_{0}\right)^{n}-1}{\left(1+i_{0}\right)^{n}}\right)\right)+\left(\frac{R_{1}}{k_{0}}\left(\frac{1}{\left(1+i_{0}\right)^{n}}-\frac{1}{\left(1+i_{0}\right)^{N}}\right)\right)\right]-\left[\left(\frac{r_{0}}{R_{A}^{T^{\prime}}}\left(\frac{\left(1+i_{1}\right)^{m}-1}{\left(1+i_{1}\right)^{m}}\right)\right)+\left(\frac{r_{I}}{k_{l}}\left(\frac{1}{\left(1+i_{1}\right)^{m}}-\frac{1}{\left(1+i_{l}\right)^{N}}\right)\right)\right]
$$

The multiplier for the term cash inflow and cash outflows in equations 6 and 7 are not straightforward compared to the preceding contemporary models because it is nested with the calculation of YP in perpetuity at $R_{A}^{T}$ and $R_{A}^{T^{\prime}}$; compound interest at $Y_{A}$ and $Y^{\prime}{ }_{A}$; and PV of at $Y_{A}$ and $Y_{A}^{\prime}{ }_{A}$ respectively, whereas the discounting of term rents received and paid in the UK growth explicit models was with recourse to the equated yield on the condition that $k_{0}=e$ for non-growth incomes (Crosby, 1984; Baum \& MacGregor, 1992; Ifediora, 2005). The reversionary components of cash inflow and cash outflow in equation 7 indicate that the "slicing off" factor for both rent received and paid is multiplied by the YP in perpetuity at their respective all risks yield to reduce the YP figure to that of commensurate terminal investments.

\subsubsection{The differences between the leasehold rational- and real value valuation models}

With respect to the explicit DCF valuation of leasehold investment properties, Table 1 summarizes the differences among the family of rational and real value models. In spite of the differences in the appearance and variation in the form, structure, templates, and inputs of both families of the real value model, Crosby et al. (1997) have adjudged the models to have produced identical valuations.

Table

Differences between the family of leasehold rational- and real value models

\begin{tabular}{clll}
\hline $\mathrm{S} / \mathrm{N}$ & \multicolumn{2}{c}{ Family of leasehold rational models } & \multicolumn{1}{c}{ Family of leasehold real value models } \\
\hline 1 & $\begin{array}{l}\text { Deployed in the valuation of nominal } \\
\text { cash flows. }\end{array}$ & Deployed in the valuation of real cash flows. \\
\hline 2 & $\begin{array}{l}\text { Always implicit about rent review } \\
\text { periods. }\end{array}$ & $\begin{array}{l}\text { Depending on the formula, it could be } \\
\text { implicit or explicit about rent review periods. }\end{array}$
\end{tabular}

3 Capitalize reversionary income is deferred for the number of years to next Capitalize reversionary income is deferred for rent review at the equated yield. the number of years to next rent review at the real discount rate or inflation risk free yield.

4 Considers the explicit treatment of rental growth rates in the valuation of cash flows.

Utilizes discount rates that are implicit about rental growth rates. (See equation 16). If desirable, the implied rental growth rate can be determined using appropriate formulas. (See equations 13 - 15).

5 Uses all risks yield to capitalize reversionary cash flows in perpetuity; Where $\frac{1}{k_{0}}$ is not used, the real value model utilizes an embedded surrogate function of 


\begin{tabular}{|c|c|c|}
\hline & that is " $\frac{1}{k_{0}} "$. & $\begin{array}{l}\text { the form: } \\
"\left(1-\frac{1}{(1+e)^{t}}\right) \div e\left(1-\frac{1}{(1+i)^{t}}\right) " \text { to capitalize } \\
\text { reversionary cash flows in perpetuity. }\end{array}$ \\
\hline 6 & $\begin{array}{l}\text { Utilizes a "slicing off" function of the } \\
\text { form: " }\left(\frac{\left(1+g_{0}\right)^{n}}{(1+e)^{n}}-\frac{\left(1+g_{0}\right)^{N}}{(1+e)^{N}}\right) \text { " in the } \\
\text { valuation of deferred reversionary cash } \\
\text { flows. }\end{array}$ & $\begin{array}{l}\text { Utilizes a "slicing off" function of the form: } \\
\left\{(\mathbf{1}+\boldsymbol{i})^{-n}-(\mathbf{1}+\boldsymbol{i})^{-N}\right\} \text { OR } \\
\text { " } \frac{1}{(1+i)^{n}}\left(1-\frac{1}{(1+i)^{N-n}}\right) \text { " in the valuation of } \\
\text { deferred reversionary cash flows. }\end{array}$ \\
\hline
\end{tabular}

Source: own study.

\subsection{Equivalent yield model for the valuation of reversionary leasehold interest}

The equivalent yield valuation technique is a conventional method of investment valuation which entails the use of a single implicit discount rate to determine the capital value of an interest in property including its term and reversion. Equation 8 below features the equivalent yield model for the valuation of reversionary leasehold investment property.

$$
P V=\left[\left(R_{0}\left(\frac{\left(1-\left(1+k_{e}\right)^{-n}\right)}{k_{e}}\right)\right)+R_{1}\left(\frac{\left(1-\left(1+k_{e}\right)^{n-N}\right)}{k_{e}\left(1+k_{e}\right)^{n}}\right)\right]-\left[r_{0}\left(\frac{\left(1-\left(1+k_{e}\right)^{-m}\right)}{k_{e}}\right)+r_{1}\left(\frac{\left(1-\left(1+k_{e}\right)^{m-N}\right)}{k_{e}\left(1+k_{e}\right)^{m}}\right)\right]
$$

While the application of the equivalent yield to freeholds has been supported by existing publications including Brown and Matysiak (2000), Isaac (2002), Scarrett (2008), and Sayce et al. (2006) among others, there appears to be a dearth of literature pertaining to the deployment of same conventional technique to the market valuation of reversionary leaseholds. However, Udo (1989), from an appraisal perspective, demonstrated the calculation of leasehold equivalent yield from results of an explicit DCF market valuation. In alignment with this aspect of the study by Udo (1989), an attempt was made to show how leasehold equivalent yield can be derived from growth explicit valuations, and demonstrate how the same yield can churn out capital value that is identical to those produced from all the explicit DCF valuation techniques including the alternative real value hybrid model developed in this article.

\section{Design of an alternative real value hybrid valuation model for reversionary leaseholds}

\subsection{Interrelated investment functions}

While the term component of all the contemporary leasehold valuation models entails the valuation of nominal cash flows using nominal rate of interest (equated yield), the system adopted for the valuation of the reversionary components is what actually sets them apart from each other. For instance, the reversionary component of the full DCF technique and the modified rational model utilizes nominal cash flows which are subjected to appropriate growth rates and capitalized at a nominal rate of interest or equated yield, while that of the real value hybrid model discounts real cash flows at the appropriate real discount rate otherwise called the inflation risk free yield.

Therefore, the relationship between nominal and real discount rates that enables the production of identical valuations across the contemporary value models was expressed by Brown and Matysiak (2000) as:

$$
1+r_{n}=\left(1+r_{r}\right)(1+\Delta)
$$

Where $r_{n}$ = equated yield (nominal rate of interest), $r_{r}=$ real rate of return (inflation risk free yield) and $\Delta=$ expected rate of inflation or the implied rental growth rate. Equation 9 is held to be true when implied rental growth rate is equal to inflation rate (that is, $g=f$ ), so that the inflation risk free yield $i$ can be derived as follows:

$$
\begin{gathered}
r_{r}=\left(\frac{1+r_{n}}{1+\Delta}\right)-1 \\
i=\frac{(1+e)}{(1+g)}-1
\end{gathered}
$$


Furthermore, the implied growth rate of cash flows, $g$ can be derived from equation 11 as:

$$
g=\frac{(1+e)}{(1+i)}-1
$$

In consonance with the seminal works of Sykes (1984); Brown and Matysiak (2000); Isaac (2002); Baum and Crosby (2007); and Wyatt (2013), similar models that have been deployed to calculate implied rental growth rates include equations 13,14 , and 15 respectively:

$$
\begin{gathered}
(1+g)^{t}=\frac{Y \text { P in Perp.@ } k-Y \text { P for tyears@e }}{Y \text { Pin Perp.@ } k \times P \text { V in tyears@e } e} \\
g=\left(\frac{(e-k)(1+e)^{t}+k}{e}\right)^{1 / t}-1 \\
g=\left(\sqrt[t]{(e-k)\left[\frac{(1+e)^{t}-1}{e}\right]+1}\right)-1
\end{gathered}
$$

A synthesis of equations 12 and 15 was used to derive an alternative formula [equation 16] which unbundles the constituents of the inflation risk free yield in equation 11 as:

$$
i=\left((1+e) \times\left(1+\left(\left(\sqrt[t]{(e-k)\left[\frac{(1+e)^{t}-1}{e}\right]+1}\right)-1\right)\right)^{-1}\right)-1
$$

Equations 13 - 15 are used to derive the implied rental growth rate to be used in DCF valuations, while equation 16 can be used to calculate the real discount rate for the valuation of real cash flows.

Going by the analogy of equations 9 to 16, real inputs have a corresponding nominal equivalent; hence, the use of nominal or real cash flows in property investment valuation remains rational provided the corresponding nominal- or real discount rate is used.

Ifediora (2005) asserts that inflation risk alone cannot explain all the differences between a future sum and its present value as yields must reflect the market assessment of all risks. This accounts for why the real return in equation 16 is a function of the nominal rate of return, $e$; the rent review period, $t$; and the all risks yield, $k$. Adams et al. (2003) opined that the value of an investment will increase in terms of local currency and simultaneously declines in real terms as a result of erosion of the purchasing power over time. Therefore, the farther away a future reversionary cash flows, the less its present value (Hoesli \& MacGregor, 2000; Ifediora, 2005), and further explains why the future sum of money is worth less than an equivalent face value held today. Therefore, an acceptable leasehold valuation model should capture growth explicit yield parameters comprising equated yield, all risk yield, rent review period, and real rate of return in order to account for the differences between the future sum and its present value equivalent.

\subsection{Synthesis of rational model with inputs for the real value model}

There are three leading arguments that have driven the zeal for an alternative real value hybrid model for the valuation of reversionary leasehold investment properties. First, Hungria-Garcia et al. (2004) concluded that it is not wrong to question existing theories because such practice provides us with a framework for understanding the dynamics of markets and help model property prices in that direction. The theory being questioned here is the possibility of simplifying the modified rational model by embedding growth and rent reviews since a knowledge of these parameters could be provided alongside the valuation without showing them in value computation. Secondly, Udo (2003) affirmed that, in the event that an existing valuation model is inadequate, the valuer could strategize by using an appropriate model or combination of models which incorporates an understanding of investors' and market behavior. Even if a valuation model is presumed adequate but could be simplified or accorded a different perspective which still aligns with the logic and results from existing models, it does not hinder exploring the possibility of model (re)design. Thirdly, Crosby (1996) and Crosby et al. (1997) admitted that all the variants of contemporary valuation models should not be construed as competing for superiority, but should rather be seen as alternative tools which 
valuers can deploy in the exercise of their trade. Therefore, to reject any possibility of simplifying the modified rational model for reversionary leasehold investments and according it a real value dimension is synonymous to throwing the baby with the bath water and denying ourselves the possibility of new discoveries. It is on the basis of these three arguments that an alternative real value hybrid model for the valuation of leaseholds was developed using a synthesis of the modified rational model and inputs associated with the real value hybrid model.

The equated yield of an investment property can be derived from equation 19 as:

$$
e=(1+g)(1+i)-1
$$

With recourse to equation 3 , the reversionary components of cash inflow and cash outflow in the modified rational model have been extracted as equations 18 and 19 respectively:

$$
\begin{gathered}
\left(\frac{R_{1}\left(1+g_{0}\right)^{n}}{k_{0}(1+e)^{n}}-\frac{R_{1}\left(1+g_{0}\right)^{N}}{k_{0}(1+e)^{N}}\right) \\
\left(\frac{r_{1}\left(1+g_{1}\right)^{m}}{k_{1}(1+e)^{m}}-\frac{r_{1}\left(1+g_{1}\right)^{N}}{k_{1}(1+e)^{N}}\right)
\end{gathered}
$$

The all risks yields, $k_{0}$ and $k_{1}$ in equations 18 and 19 respectively can be generalized to take the form of equation 20:

$$
k=e-e\left(\frac{(1+g)^{t}-1}{(1+e)^{t}-1}\right)
$$

Assuming that the reversionary rent, $R_{1}$ is unity, equation 20 is further reduced to -

$$
\left(\frac{(1+g)^{n}}{k_{0}(1+e)^{n}}-\frac{(1+g)^{N}}{k_{0}(1+e)^{N}}\right)
$$

An inspection of equation 21 indicates that " $\frac{(1+e)}{(1+i)}-1$ " in equation 12 can be substituted for $g$ :

$$
\frac{\left(x-\frac{(1+e)}{(1+i)}-x\right)^{n}}{k_{0}(1+e)^{n}}-\frac{\left(x+\frac{(1+e)}{(1+i)}-x\right)^{N}}{k_{0}(1+e)^{N}}
$$

The algebra is further resolved as:

$$
\begin{gathered}
{\left[\frac{(1+e)^{n}}{(1+i)^{n}} \times \frac{1}{k_{0}(1+e)^{n}}\right]-\left[\frac{(1+e)^{N}}{(1+i)^{N}} \times \frac{1}{k_{0}(1+e)^{N}}\right]} \\
\frac{1}{k_{0}(1+e)^{n}(1+e)^{N}}\left(\left[\frac{(1+e)^{n}}{(1+i)^{n}} \times(1+e)^{N}\right]-\left[\frac{(1+e)^{N}}{(1+i)^{N}} \times(1+e)^{n}\right]\right) \\
\frac{1}{k_{0}(1+e)^{n}(1+e)^{N}}\left(\frac{(1+e)^{n}(1+e)^{N}}{(1+i)^{n}}-\frac{(1+e)^{n}(1+e)^{N}}{(1+i)^{N}}\right)
\end{gathered}
$$

Equation 26 is obtained by factorizing equation 25 and taking out the common multiples as follows:

$$
\frac{(1+e)^{n}(1+e)^{N}\left[\frac{1}{(1+i)^{n}}-\frac{1}{(1+i)^{N}}\right]}{k_{0}(1+e)^{n}(1+e)^{N}}
$$

Therefore, an alternative way of expressing the modified rational model for the valuation of reversionary leasehold cash inflows within the real value perspective is given as: 


$$
\frac{1}{k_{0}}\left[\frac{1}{\left(1+i_{0}\right)^{n}}-\frac{1}{\left(1+i_{0}\right)^{N}}\right]
$$

Similarly, if the procedure in equations 21 to 26 was repeated for the reversionary component of rent paid, $r_{1}$ in equation 3 , then an alternative way of expressing the modified rational model for the valuation of reversionary leasehold cash outflows within the real value perspective is given as:

$$
\frac{1}{k_{1}}\left[\frac{1}{\left(1+i_{1}\right)^{m}}-\frac{1}{\left(1+i_{1}\right)^{N}}\right]
$$

The principle behind the reversionary income multipliers in equations 35 and 36 has been tagged as "slicing off" (Jefferies, 2009; Jefferies, 2016). In other words, the capitalization of cash flows in perpetuity [See equations 27 and 28] and multiplication by the differential arising from the "slicing off" process - $\left[\left(1+i_{0}\right)^{-n}-\left(1+i_{0}\right)^{-N}\right]$ and $\left[\left(1+i_{1}\right)^{-m}-\left(1+i_{1}\right)^{-N}\right]$ were designed to reduce the real value of the deferred YP factor to an equivalent multiplier for terminal investments like leaseholds. This feat is

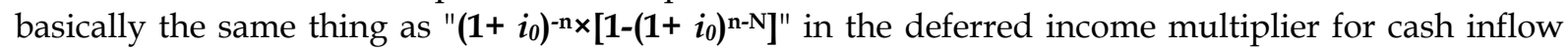

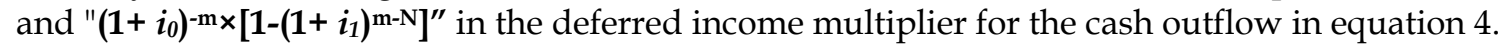

Equations 27 and 28, being a synthesis of the rational/real value hybrid model, implicitly reflect rental growth and deferment of ordinary annuity multiplier taking into cognizance all risks inherent in leaseholds prominent among which is the diminution of capital value upon expiry of the tenure.

\subsection{The alternative Real Value hybrid model}

With recourse to equations 27 and 28 , the alternative real value hybrid model for the valuation of reversionary leaseholds developed from a synthesis of the modified rational model with the elements of the fundamental real value hybrid model is expressed as:

$$
P V=\left[\left(R_{0}\left(\frac{\left(1-(1+e)^{-n}\right)}{e}\right)\right)+\left(\frac{R_{I}}{k_{0}}\left(\frac{1}{\left(1+i_{0}\right)^{n}}-\frac{1}{\left(1+i_{0}\right)^{\mathrm{v}}}\right)\right)\right]-\left[r_{0}\left(\frac{\left(1-(1+e)^{-m}\right)}{e}\right)+\left(\frac{r_{l}}{k_{I}}\left(\frac{1}{\left(1+i_{l}\right)^{m}}-\frac{1}{\left(1+i_{l}\right)^{\mathrm{v}}}\right)\right)\right]
$$

where all the inputs in equation 29 retain their original meanings as detailed in the second section of this article. For the valuation of rent received and rent paid respectively, the term rents in equation 29 shall be discounted using the equated yield just as in the other variants of the contemporary value models. Unlike Crosby's real value hybrid model which entails the calculation of a composite 3-in-1 YP function to arrive at the reversionary income multiplier, the alternative real value hybrid model is devoid of such composite YP function by mimicking the modified rational model and the generic real value model in the use of YP in perpetuity function. Specifically, the reversionary cash flow valuation components in the alternative real value hybrid model exhibits so much in common with the reversionary cash flow valuation components of Jefferies' generic real value model in equation 6 and further incorporates inputs similar to the Crosby's real value hybrid model in equation 4 pertaining to the equated yield, inflation risk free yield, period to the next rent review, and the duration of reversionary income calculated as the difference between the entire term and the period to the next rent review. When compared with Crosby's real value hybrid model in equation 4 , the alternative real value hybrid model in equation 29 is implicit about rent revision periods by virtue of equations 16 and 20 respectively.

\subsection{Model application and validation techniques}

A case of reversionary leasehold investment property characterized by regular review of sub-rents received and regular review of head rent paid at unequal intervals [See Figure 1] was used to test the alternative real value hybrid model for reversionary leasehold valuation [equation 29] developed in this article. As highlighted in Figure 2, the inflation risk free yields and all risks yields for leasehold cash inflow and cash outflow in the valuation case study were determined using spreadsheet equivalents of equations 11 and 20 respectively. Validation of the alternative real value hybrid model was instantiated using the following existing contemporary value models within the Microsoft ${ }^{\circledR}$ Excel $^{\circledR}$ environment:

1) The full explicit DCF Valuation model described in section 2.3.1,

2) The modified rational model [Equation 3],

3) The real value hybrid model [Equation 4], and 
4) Jefferies' generic real value model [Equation 6].

Upon completion of the market valuation using the five variants of contemporary models, a WhatIf analysis was carried out to determine the conventional leasehold equivalent yield. Thereafter, an inductional calculation was carried out using equation 8 to verify the extent to which the leasehold equivalent yield could be used to derive capital value identical to those churned out from the five variants of contemporary value models including the alternative real value hybrid model developed in the course of this study. Data analysis and valuations in this study were instantiated using Microsoft ${ }^{\circledR}$ Excel $^{\circledR}$ for the purpose of formula auditing, consistent valuations, and a zero tolerance for errors due to rounding off. Valuations were expressed in integer and two decimal place-currency of the Naira and Kobo as obtained in Nigeria. Unless otherwise stated, all tables, diagrams, and screenshots in this article are products of the author's own study.

\section{Empirical results}

\subsection{Reversionary leasehold valuation case study}

The case study pertains to a leasehold interest having an unexpired term of 24 years. The leasehold interest which commands a market sub-rent of $\$ 3,020,000$ per annum (reviewable 3 yearly) is currently held under a sublease for the sum of $\$ 2,180,000$ per annum (reviewable 3 yearly) which shall be due for upward revision in 2 years' time. The lessee who currently paid the sum of $\$ 805,000$ per annum (reviewable 5 yearly) is expecting an upward revision in 3 years' time to an equivalent market head rent of 905,500 per annum (reviewable 5 yearly). Market analysis indicates $23 \%$ nominal rate of return, while cash inflows and cash outflows for similar investments grow at the rate of $17.45 \%$ per annum and $14.18 \%$ per annum respectively.

\subsection{Data specification}

For this case study, the deployment of the five variants of contemporary models of reversionary leasehold valuations including the alternative real value hybrid model developed in this paper requires a total of seventeen (17) data. Twelve of these data have been supplied in the case study. Among the remaining five (5) data highlighted in Figure 2, the inflation risk free yield of the leasehold income, the inflation risk free yield of the freehold income, all risk real yield of contract rent received, and the all risk real yield of head rent paid were derived using the appropriate formula examined in the preceding section, while the initially unknown equivalent yield for the leasehold investment property was determined using scenario analysis on completion of the valuation exercise.

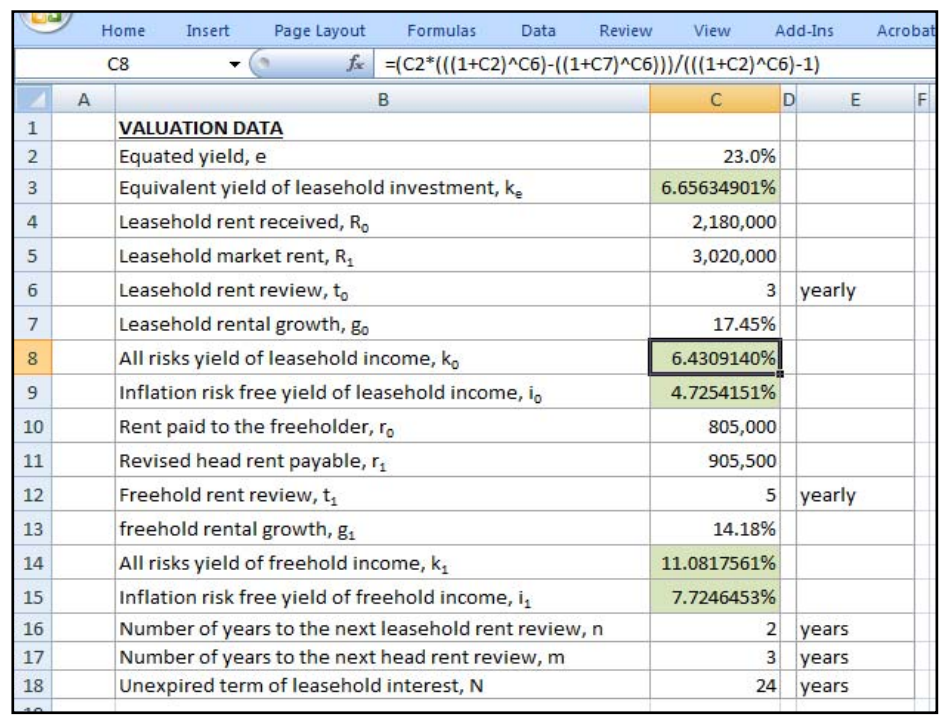

Fig. 2. Valuation data with pre-calculated inputs in green. Source: own study.

\subsection{Valuation of reversionary leasehold using the alternative real value hybrid model}

For the alternative real value hybrid model [equation 29], passing sub-rent and the head rent paid were discounted using the equated yield to arrive at $\$ 3,213,298.96$ and $\$ 1,619,156.29$ respectively as 
indicated in Figure 3. The calculation of the multipliers for reversionary cash flows commenced with the determination of the YP in perpetuity at the all risks yield and adjusted using the difference between present value of $\$ 1$ in the period to the next rent review and the present value of $\$ 1$ in the unexpired term of the lease at the inflation risks free yield. This exercise returned 9.0440 and 5.7055 as the adjusted multipliers for reversionary rent received and rent paid respectively. The application of the alternative real value hybrid model [Figure 3] produced capital value of rent received to the tune of $\$ 30,526,222.67$ and capital value of rent paid to the tune of $\$ 6,785,504.23$, the difference of which amounts to a leasehold capital value of $\$ 23,740,718.44$.

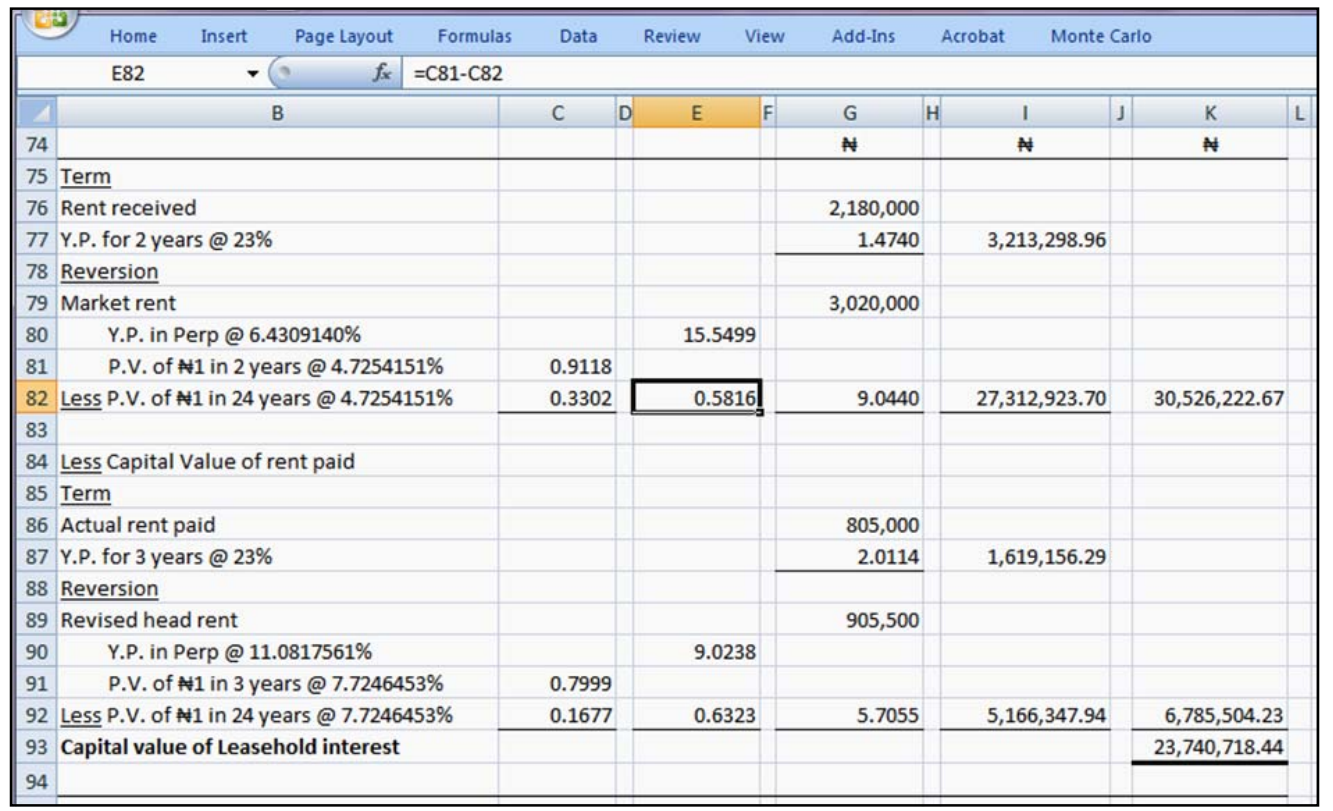

Fig. 3. Valuation of leasehold interest using the alternative real value model. Source: own study.

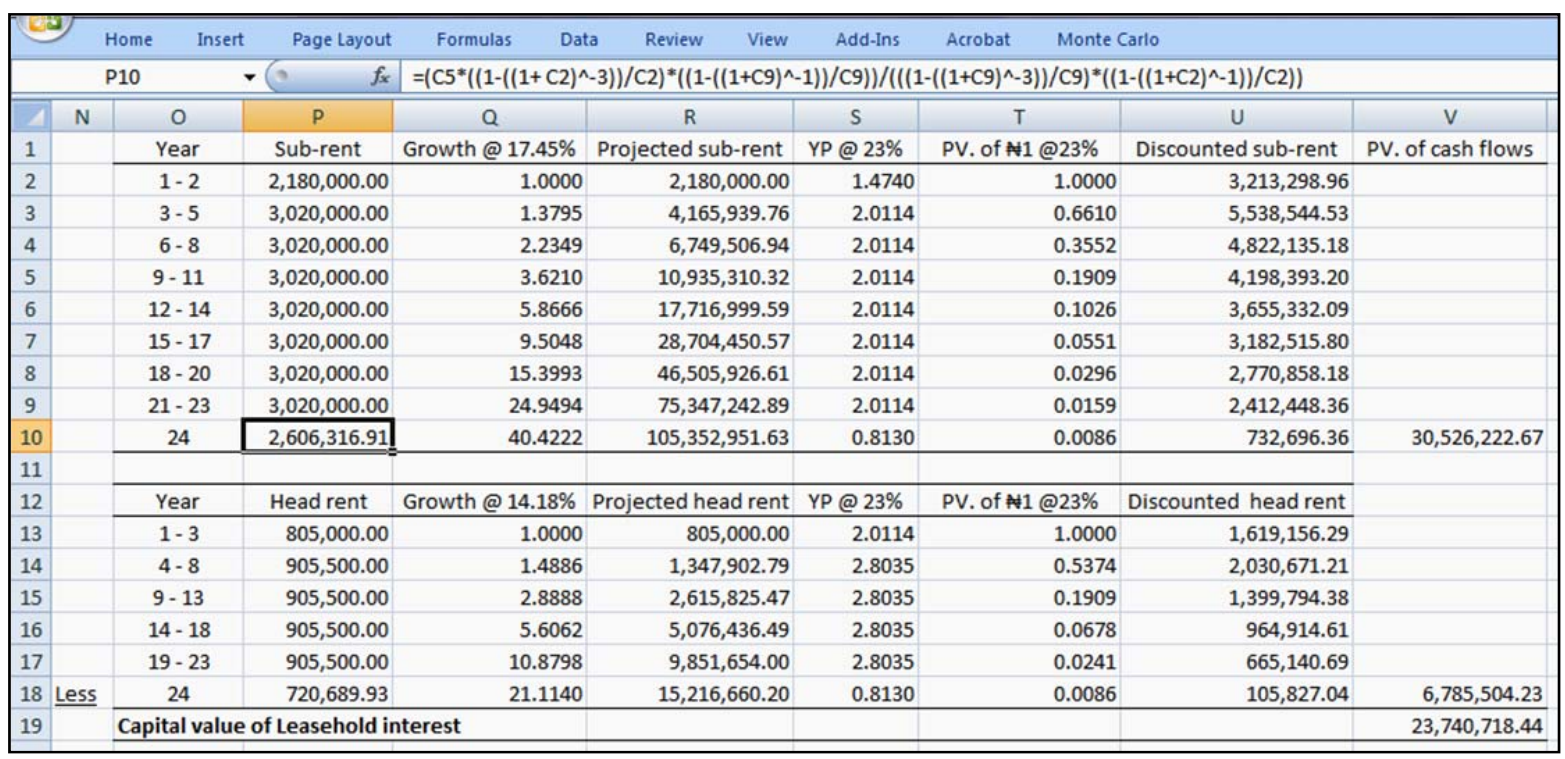

Fig. 4. The full explicit DCF valuation of reversionary leasehold investment property. Source: own study.

\subsection{Validating the alternative real value hybrid model using existing contemporary models}

The valuation churned out from the alternative real value hybrid model developed in this article was validated using the valuations produced by the four existing contemporary models.

\subsubsection{The full explicit DCF valuation of reversionary leasehold}


With respect to Figure 4, the separation of the present value of cash inflow from the present value of cash outflow remains the norm for all the contemporary models for the valuation of reversionary leasehold interest.

What would have been the capitalized profit rent in conventional terms represents the difference between capital values of sub-rent received and head rent paid. In Figure 4, the nominal rents received and paid during the last tranches were adjusted to the annual equivalent of $N 2,606,316.91$ and $\$ 720,689.93$ using equation 1 or 2 . Validating the results from the alternative real value hybrid model is a DCF valuation of the same leasehold interest to the tune of $\$ 23,740,718.44$ being the difference between $\$ 30,526,222.67$ discounted cash inflow and $\$ 6,785,504.23$ discounted cash outflow.

\subsubsection{Valuation of reversionary leaseholds using a variant of the modified rational model}

Just as in the valuations in Figures 3 and 4, the capital value of passing sub-rent and the head rent paid following the use of a variant of the modified rational model in Figure 5 indicated the sum of $\$ 3,213,298.96$ and $\$ 1,619,156.29$ respectively.

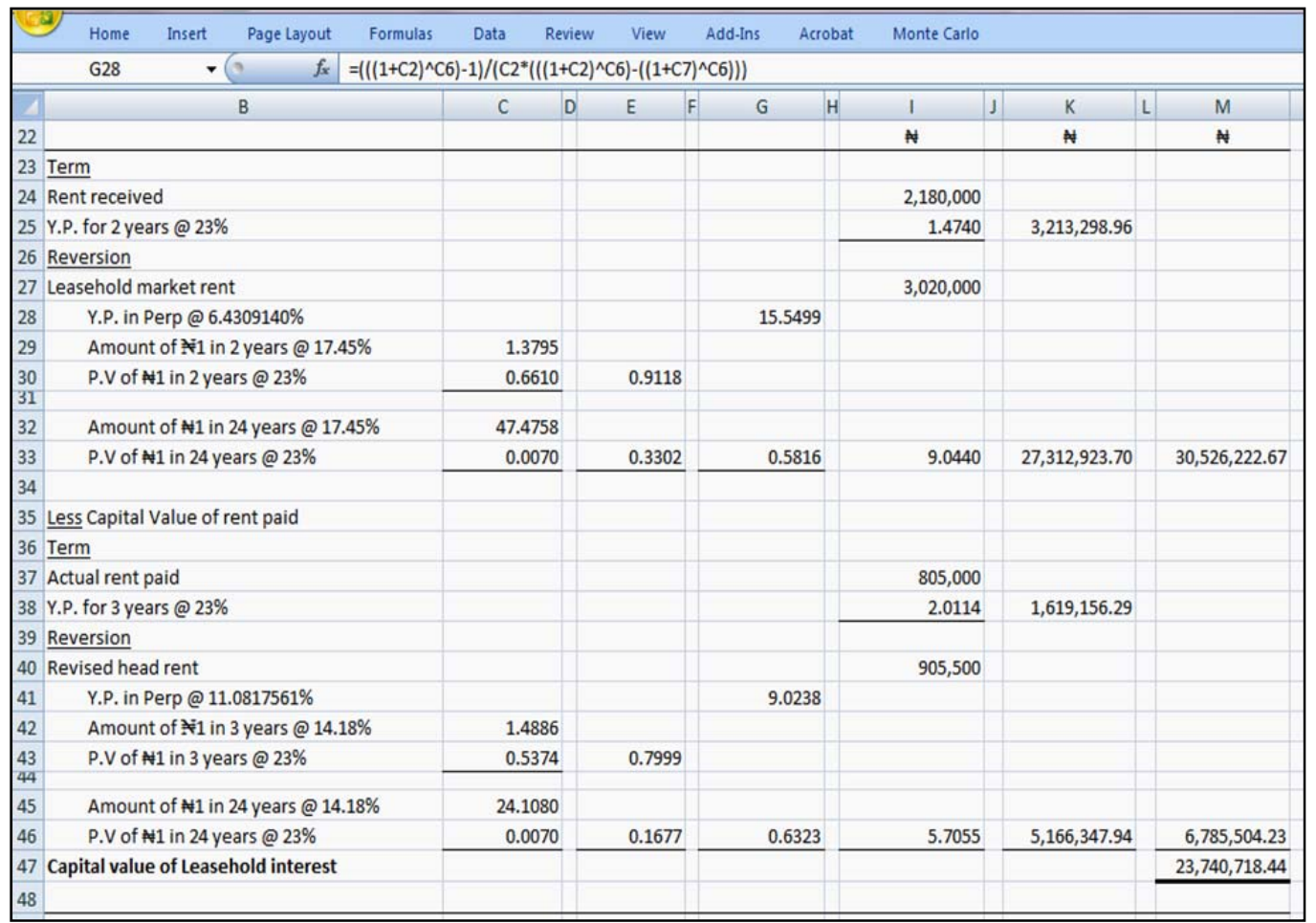

Fig. 5. Valuation of leasehold interest using a variant of the modified rational model. Source: own study.

The valuation in Figure 5 was instantiated in consonance with equation 3 so that the difference between discounted cash inflow of $\$ 30,526,222.67$ and discounted cash outflow of $¥ 6,785,504.23$ amounts to leasehold capital value of $\$ 23,740,718.44$. Therefore, the capital value of leasehold interest churned out by this variant of the modified rational model in Figure 5 is identical to the valuation obtained using the alternative real value hybrid model in Figure 3 and the full explicit DCF valuation technique in Figure 4.

\subsubsection{Valuation of reversionary leasehold using the real value hybrid model}

In consonance with the discounting of term rents using the nominal yield in Figures 3, 4 and 5, the capital value of passing sub-rent and the head rent paid following the use of the Crosby's real value hybrid model in Figure 6 indicated the sum of $\$ 3,213,298.96$ and $\$ 1,619,156.29$ respectively. The only exception however, was the treatment of reversionary cash inflows and cash outflows. The 3-in-1 income multiplier model deployed in Figure 6 incorporated analytical surrogates for the implicit forecast of cash flows and the valuation of a unit of the forecast cash flow using the real yield in order to arrive at 9.0440 and 5.7055, being YPs for the period to reversion deferred over the period to the next revision of market rent, and found to be identical to income multipliers found in the application 
of the alternative real value hybrid model and the modified rational model in Figures 3 and 5 respectively.

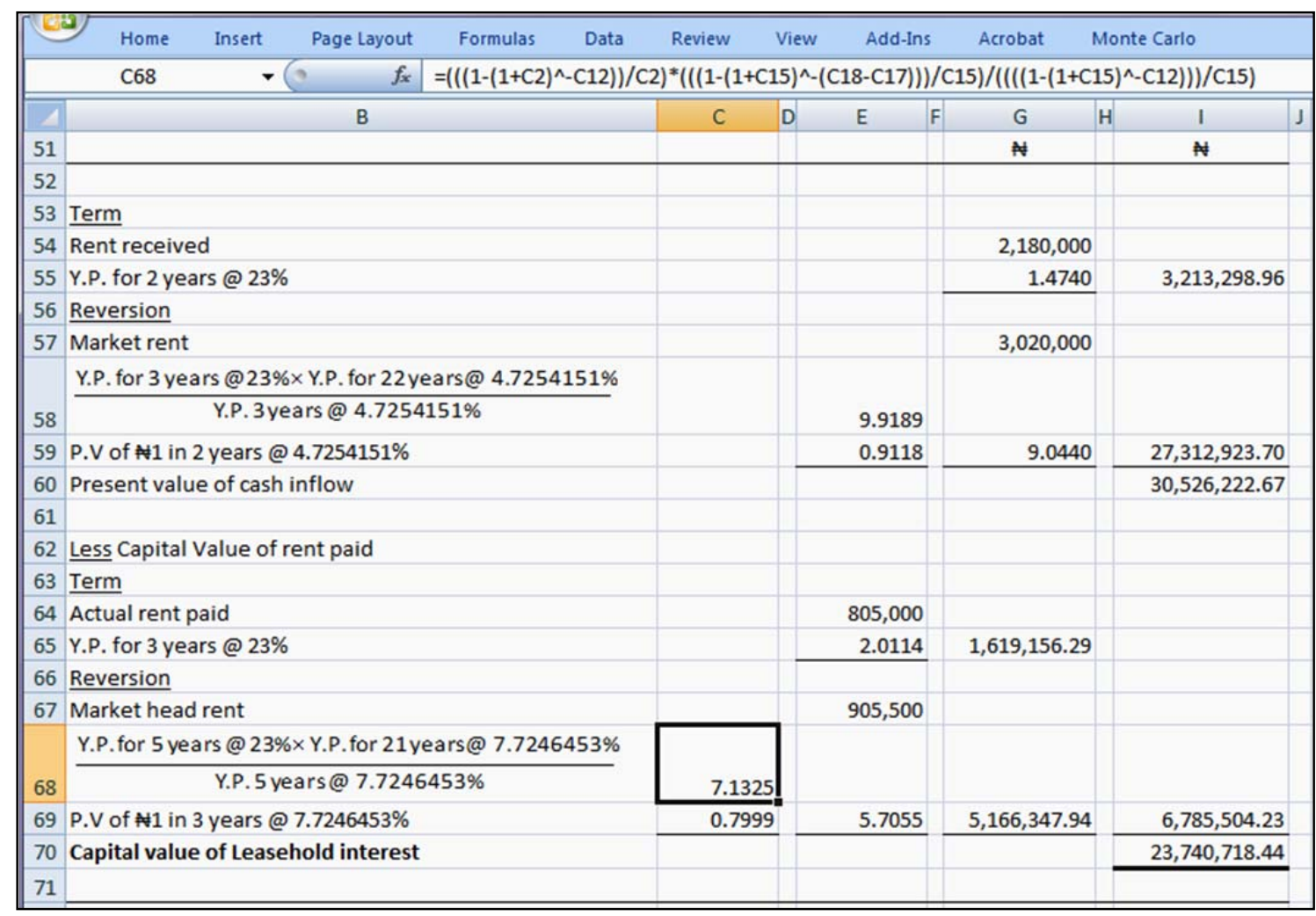

Fig. 6. Valuation of leasehold interest using the real value hybrid model. Source: own study.

Just as in the application of the alternative real value hybrid model [Figure 3] and the modified rational model [Figure 4], the real value hybrid model returned a leasehold capital value of N23,740,718.44 being the difference between capital value of rent received to the tune of $\$ 30,526,222.67$ and capital value of rent paid to the tune of $\$ 6,785,504.23$. For the case of the leasehold interest under review, there is a convergence of valuations across these models.

\subsubsection{Valuation of reversionary leasehold using the Jefferies' generic real value model}

In contrast with the variants of the existing contemporary models, the discounting of term rents in the generic real value model does not entail the use of the equated yield or the "overall required yield rate" (Jefferies, 2010). Instead, the term rent in Figure 7 was valued using a combination of the inflation risk free yield unique to the entire cash inflow or cash outflow, and the unique all risks yield attributed to the term rents received or paid respectively.

The structure for the valuation of reversionary cash inflows and cash outflows in Figure 7 appears identical to that in the alternative real value hybrid model in Figure 3 except for the variation in symbolisms across the input variables. Just as in Figure 3, the reversionary YPs in Figure 7 were adjusted using the "slicing off" function which is the difference between Present Value of 11 in the period to the next rent review and the Present Value of $\$ 1$ in the unexpired term of the lease at the inflation risks free yield. The "slicing off" culminated into 9.0440 and 5.7055 as the adjusted multipliers for reversionary rent received and rent paid respectively.

Just as in the application of the contemporary value models in Figures 3, 4, 5, and 6, the generic real value model produced capital value of rent received to the tune of $\$ 30,526,222.67$ and capital value of rent paid to the tune of $\$ 6,785,504.23$, the difference of which amounts to a leasehold capital value of $\$ 23,740,718.44$. In other words, the four contemporary valuations applied to verify the leasehold valuation churned out by the alternative real value hybrid model returned identical capital values for the term and reversion respectively. + 


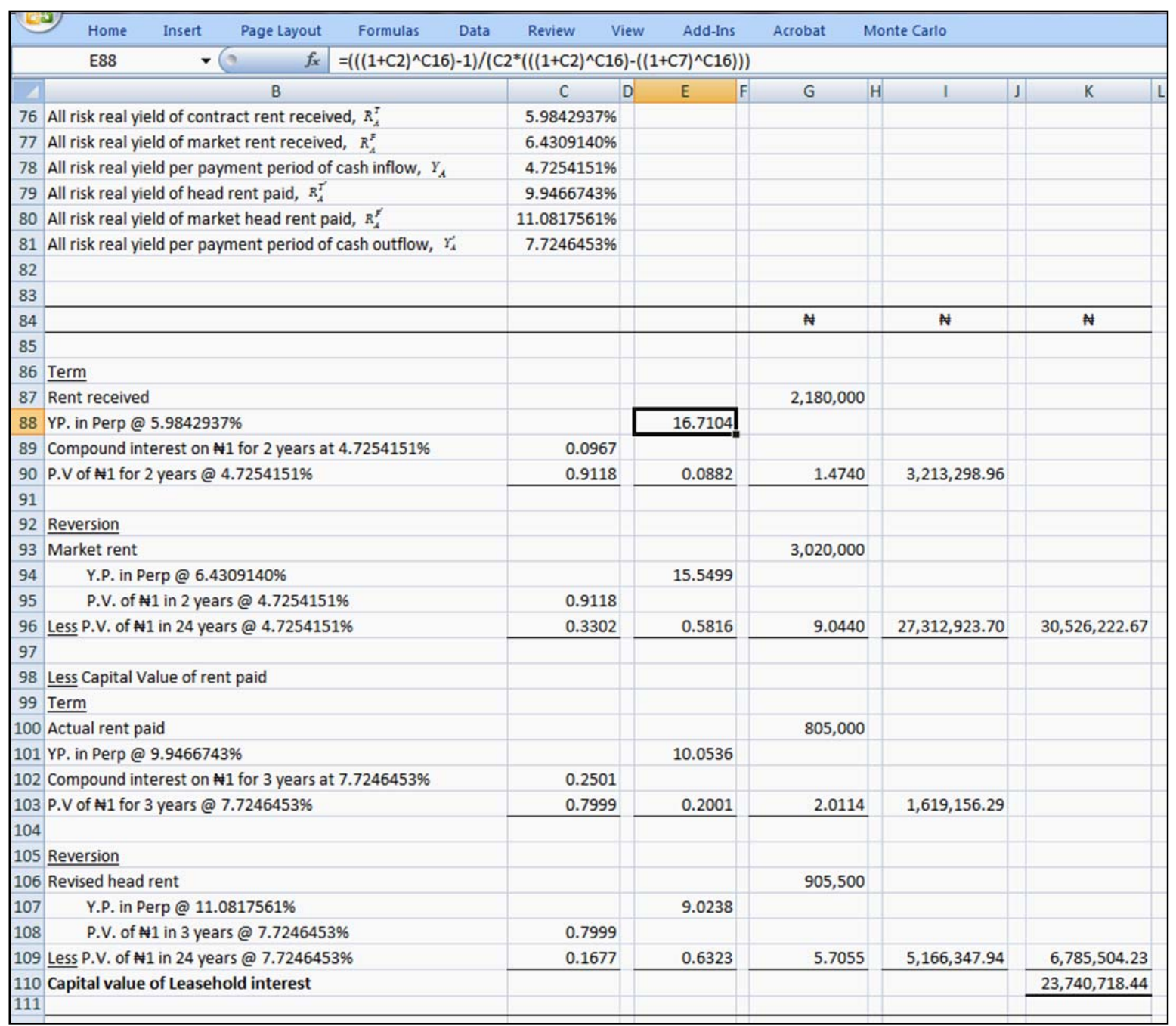

Fig. 7. Valuation of leasehold interest using the all risks real yield (ARRY) model. Source: own study.

While objectivity of data collection and spreadsheet automation of valuation could immune the generic real value model from possible erroneous assumptions and calculations as argued by Jefferies (2016), insight from Figure 7 shows that the generic real value model is characterized by methodological complexity.

\subsection{Appraising the conventional leasehold equivalent yield}

The procedure for the appraisal of the equivalent yield $k_{e}$ commenced with the setting out of data and a formula audited valuation template in Figure 8. Instantiating Goal Seek function in Excel ${ }^{\circledR}$ returned $6.65634901 \%$ as the leasehold equivalent yield so that, by uniformly discounting the leasehold cash inflows and cash outflows at this rate of return, it shall churn out leasehold capital value in the sum of N23,740,718.44, which is identical to capital values obtained from the five variants of contemporary value models including the alternative real value hybrid model developed in this article. Hence, the appropriate value for the empty cell "C3" in Figure 2 is put at $6.65634901 \%$.

\section{Discussions and conclusion}

The alternative real value model developed in this study is a synthesis of the modified rational model credited to Baum and Shi Ming (1985b) on the one hand, and the real value hybrid model credited to Crosby $(1983,1984)$ on the other hand. With respect to the alternative real value/short-cut DCF model developed in this article, term rents received and payable are discounted using the equated yield as in the other variants of the UK contemporary value models, while the reversionary cash inflow and cash outflow are valued using a multiplier determined as a product of YP in perpetuity at the all risks yield 
and a slicing off function designed to reduce the real value of the deferred YP factor to an equivalent multiplier for terminal investments like leaseholds. In other words, the valuation of reversionary cash flows in this alternative real value model appears identical to that found in the Jefferies' generic real value model by virtue of the following seminal works - Jefferies (1997a), Jefferies (1997b), Jefferies (2009), and Jefferies (2010).

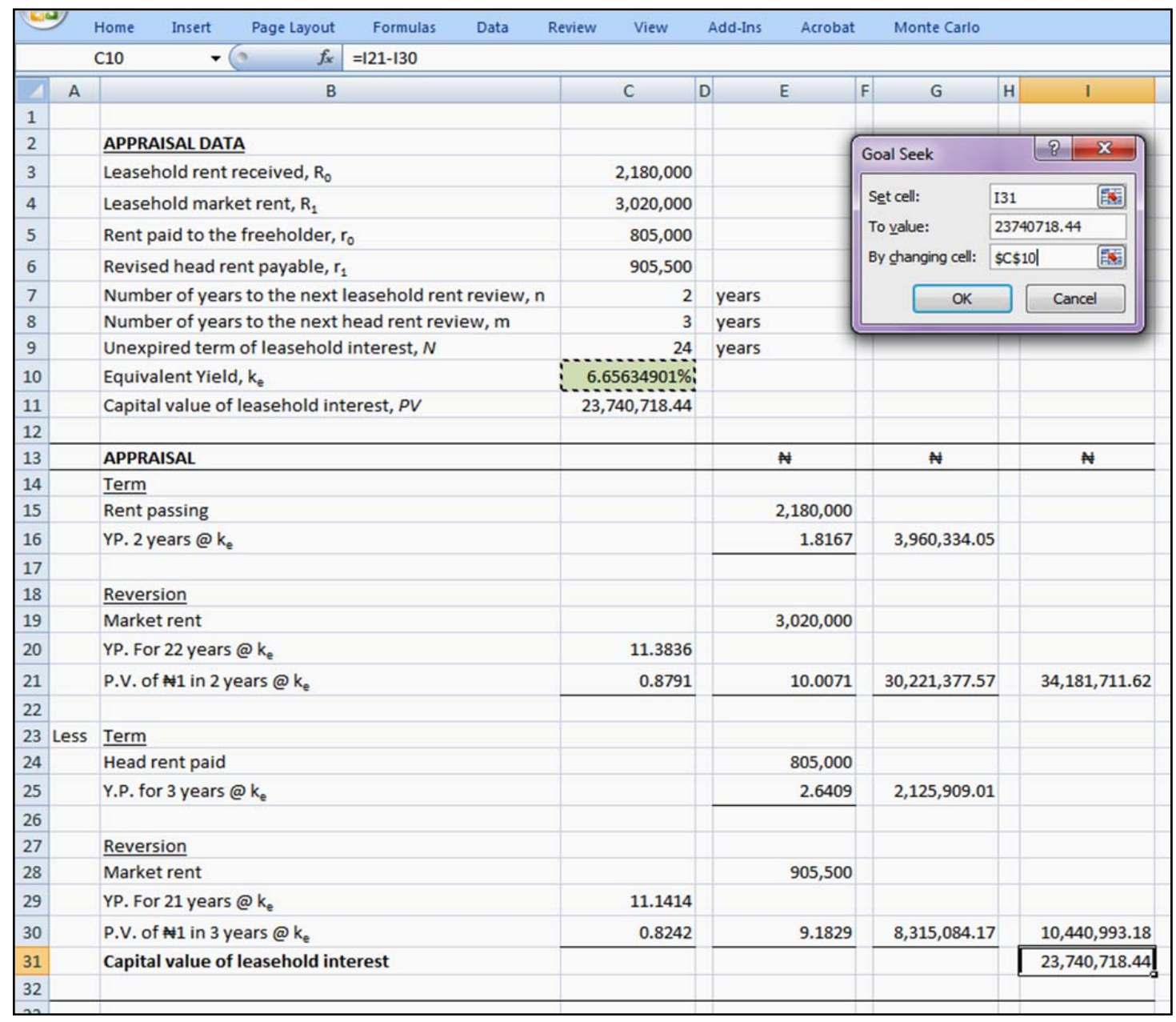

Fig. 8. Conventional equivalent yield calculation for leasehold investment property. Source: own study.

Unlike Crosby's real value hybrid model, which entails the calculation of a composite 3-in-1 YP function to arrive at the reversionary income multiplier, the alternative real value hybrid model is devoid of such composite YP function but instead mimics the modified rational model and the generic real value model in the use of YP in perpetuity function. Furthermore, the reversionary cash flow valuation components in the alternative real value hybrid model contain input variables similar to Crosby's real value hybrid model in equation 4, especially in the requirement of the equated yield, inflation risk free yield, period to the next rent review, and the duration of reversionary income; but remains implicit about rental growth and rent revision periods by virtue of equations 16 and 20 respectively.

Crosby (1996) and Crosby et al. (1997) could be recalled as having given credence to the existence of an array of contemporary value models and stressing more on their complementarities rather than relative supremacy. In tandem with this view, the test and validation of the alternative real value hybrid model for leasehold valuations has maintained consistent results with existing contemporary models and appears to be relatively compact. The development of an alternative real value hybrid model in this article is a first attempt towards redesigning the modified rational model of leasehold investment valuation and according it a "real value" perspective after over three decades of the evolution of the rational model and after more than two decades since sustained scholarly efforts towards evolving similar contemporary models of property investment valuation had declined. 
Sadly though, the alternative real value hybrid model belongs to an array of contemporary value models which have been relegated by valuers in the UK and other commonwealth countries (Jefferies, 2010; Babawale, 2012; Crosby \& Henneberry, 2016; Kucharska-Stasiak, 2019). It is equally feared that the discoveries in this study may be jettisoned by a body of practitioners who have long dreaded the (re)design and simplification of valuations models even in this century. Valuers in this category should be aware that they are confronted with the inescapable challenge of continuously reviewing their tools of trade. The argument here is not about the best valuation model, or the best user-friendly model, but valuation models that simply reflect price determination in the property market without necessarily being that simple. Just as the contemporary value models that existed before it, the alternative real value hybrid model developed in this article appropriately fits into this description.

\section{References}

Adams, A., Booth, P., Bowie, D., \& Freeth, D. (2003). Investment Mathematics. John Wiley \& Sons Ltd. Ajayi, C. A. (1998). Property Investment Valuation and Analysis. De-Ayo Publications.

Babawale, G. K. (2012). Paradigm Shift in Investment Property Valuation Theory and Practice: Nigerian Practitioners'. Response Mediterranean Journal of Social Sciences, 3(3), 217-228.

Baum, A., \& Butler, D. (1986). The Valuation of Short Leasehold Investments. Journal of Valuation, 4(4), 342-353. https://doi.org/10.1108/eb007998

Baum, A.E. \& MacGregor, B.D. (1992). The Initial Yield Revealed: Explicit Valuations and the Future of Property Investment. Journal of Property Valuation and Investment, 10(4), 709-726. https:/ / doi.org/10.1108/14635789210031334

Baum, A., \& Shi Ming, Y. (1985a). The Valuation of Leaseholds: A Review: Part I. Journal of Property Valuation and Investment, 3(2), 157-166. https://doi.org/10.1108/eb007972

Baum, A., \& Shi Ming, Y. (1985b). The Valuation of Leaseholds: A Review: Part II. Journal of Property Valuation and Investment, 3(3), 230-247. https://doi.org/10.1108/eb007973

Baum, A. E., \& Crosby, N. (2007). Property Investment Appraisal (3rd ed.). Blackwell Publishing Ltd.

Baum, A. E., Mackmin, D., \& Nunnington, N. (2011). The Income Approach to Property Valuation (6th ed.). Elsevier.

Brown, G., \& Matysiak, G. (2000). Real Estate Investment: A Capital Market Approach. Financial Times-Prentice Hall.

Colam, M. (1984). The Single rate valuation of Leaseholds. Journal of Valuation, 2(1), 14-18. https://doi.org/10.1108/eb007945

Crosby, N. (1983). The Investment method of Valuation: A real value approach: 1. Journal of Valuation, 1(4), 341-350. https://doi.org/10.1108/eb007937

Crosby, N. (1984). The Investment method of Valuation: A real value approach: 2. Journal of Valuation, 2(1), 48-59. https://doi.org/10.1108/eb007948

Crosby, N. (1986a). The application of Equated Yield and Real Value Approaches to Market Valuation 1: The Logic of Techniques and the Analysis of Comparables. Journal of Valuation, 4(2), 158-169. https://doi.org/10.1108/eb007991

Crosby, N. (1986b). The application of Equated Yield and Real Value Approaches to Market Valuation 2: Equivalent Yield or Equated Yield Approaches? Journal of Valuation, 4(3), 261-274. https://doi.org/10.1108/eb007995

Crosby, N. (1986c). Real Value, Rational Model, D.C.F.: A Reply. Journal of Valuation, 4(1), 16-20. https://doi.org/10.1108/eb007984

Crosby, N. (1996). Valuation and arbitrage: A Comment. Journal of Property Research, 13, 211-220. https://doi.org/10.1080/09599916.1996.9965069

Crosby, N., French, N., \& Ward, C. (1997). Contemporary UK market valuation methods for overrented investment properties: A framework for risk adjustment. Journal of Property Research, 14, 99115. https://doi.org/10.1080/095999197368663

Crosby, N., \& Henneberry, J. (2010). Changing Investment Valuation Practices in the UK. Paper presented at the Annual Conference of the European Real Estate Society, Milan.

Crosby, N., \& Henneberry, J. (2016). Financialisation, the valuation of investment property and the urban built environment in the UK. Urban Studies (Edinburgh, Scotland), 53(7), 1424-1441. https://doi.org/10.1177/0042098015583229

Elias, T. O. (1971). Nigerian Land Law (4th ed.). Sweet \& Maxwell. 
Fraser, W. D. (1993). Principles of Property Investment and Pricing (2nd ed.). Macmillan. https://doi.org/10.1007/978-1-349-13311-6

French, N. (2012). The discounted cash flow method for property appraisals. Journal of Property Investment \& Finance, 30(3), jpif.2012.11230caa.002. Advance online publication. https://doi.org/10.1108/jpif.2012.11230caa.002

Harvey, J., \& Jowsey, E. (2004). Urban Land Economics (6th ed.). Palgrave Macmillan. https://doi.org/10.1007/978-1-137-10336-9

Hoesli, M., \& MacGregor, B. (2000). Property Investment: Principles and Practice of Portfolio Management. Pearson Education Ltd.

Hungria-Garcia, R., Lind, H., \& Karlsson, B. (2004). Property yields as tools for valuation and analysis. Stockoholm. Royal Institute of Technology.

Ifediora, B. U. (2005). Valuation Mathematics for Valuers and other Financial and Investment Analysts. Immaculate Publications Ltd.

Isaac, D. (2002). Property Valuation Principles. Palgrave.

Jefferies, R. (2010). Real Value Valuation for Property in the 21st Century? A comparison of conventional and real value models. Pacific Rim Property Research Journal, 16(4), 435-457. https:// doi.org/10.1080/14445921.2010.11104313

Jefferies, R. L. (2009). A brief history and development of 'Real Value' Valuation Models - The last four decades. Paper presented at the Pacific Rim Real Estate Society Conference, Sydney, Australia.

Jefferies, R. L. (1997a). A generic 'real value' valuation model. Paper presented at the 2nd European Real Estate Society Conference, European Business School, Berlin, Germany

Jefferies, R. L. (1997b). A 'real value' lessor's and lessee's interest valuation model. Paper presented at the 2nd European Real Estate Society Conference, European Business School, Berlin, Germany

Jefferies, R. L. (2016). All Risks Real Yield (ARRY) Investment Property Appraisal and Valuation Model - Theory \& Practice [A research monograph]. An explanation of the All-Risks Real Yield (ARRY) Investment Property Valuation and Analysis Model its theory, practice and uses. Retrieved from https:/ / dx.doi.org/https:// doi.org/10.13140/RG.2.2.34901.63208

Jefferies, R. L. (2018). Real estate real value investment valuation handbook: A Handbook explanation of the All-Risks Real Yield (ARRY) Investment Property Valuation model. Retrieved from https://www.researchgate.net/publication/328597397_Real_estate_real_value_investment_valuat ion_-_Handbook

Kucharska-Stasiak, E. (2019). Valuation schools and the evolution of the income approach. An evaluation of change trends. Real Estate Management and Valuation, 27(2), 66-76. https://doi.org/10.2478/remav-2019-0016

Marshall, P. (1976). Equated yield analysis. Estates Gazette, 239, 493-497.

McIntosh, A., \& Sykes, S. (1983). Towards a standard property income valuation model: Rationalisation or Stagnation? Journal of Property Valuation and Investment, 1(2), 117-135. https://doi.org/10.1108/eb007927

Olajide, S. E., Lizam, M., \& Olajide, E. B. (2016). Understanding The Conceptual Definitions of Cost, Price, Worth and Value. IOSR Journal of Humanities and Social Science, 21(09), 53-57. https:// doi.org/10.9790/0837-2109015357

Sayce, S., Smith, J., Cooper, R., \& Venmore-Rowland, P. (2006). Real Estate Appraisal; Value and Worth. Blackwell Publishers.

Scarrett, D. (2008). Property Valuation: The five methods (2nd ed.). Taylor \& Francis. https://doi.org/10.4324/9780203961810

Smith, I. O. (2007). Practical Approach to Law of Real Property in Nigeria (2nd ed.). Ecowatch Publications.

Sykes, S. G. (1984). Property Valuation: A Rational Model. Journal of Valuation, 2(3), 258-270. https://doi.org/10.1108/eb007956

Udo, G. O. (1989). Modern Techniques of Property Investment Valuation: The Nigerian Response. The Estate Surveyor and Valuer, 13(1), 19-24.

Udo, G. O. (2003). Model Building in Property Valuation. Enugu: Institute for Development Studies, University of Nigeria. Campus.

Wood, E. (1986). Positive valuation methods: 2. Journal of Valuation, 4(2), 170-184. https://doi.org/10.1108/eb007992

Wyatt, P. (2013). Property Valuation (2nd ed.). Wiley-Blackwell. 